\title{
Taşra Tersanelerinde Gemi Yapımı ve Mütesellimlerin Gemi İnşa Faaliyetleri (XVIII. Yüzyıl)
}

\author{
The Shipbuilding Activities of the Mütesellim in the $18^{\text {th }}$ century and \\ Shipbuilding in the Rural Shipyards
}

\begin{abstract}
Fatma ŞIMSSEK *
$\ddot{O}_{z}:$ Bahriye teşkilatıyla ilgili araştırmalarda; kurumun nitelik ve işleyişinin ortaya konulması bakımından merkez ve taşra unsurlarının incelenmesi elzemdir. Özellikle gemi inşa faaliyetlerinden bahsedilecekse eğer söz konusu bu unsurlar daha da önem kazanır. Çünkü gerek merkezde gerek ise taşrada faaliyet gösteren tersanelerin niteliklerinin ve işleyişlerini belirleyen en temel şey, işgücü ve malzeme ihtiyaçlarının karşılanması bakımından birbirlerine duydukları bağımlılıktı. Bu bağımlılık kaçınılmaz olarak merkeztaşra tersaneleri arasında sıkı bir denetim mekanizmasını ve iletişimi gerektirmişti. Fakat XVII. yüzyıldan itibaren Osmanlı idari organizasyonun temel birimlerinden olan sancaklarda görülen yapısal ve işlevsel dönüşümler bu bağımlılık ilişkilerini de değiştirmişti. Çalışmamızda bir yönüyle gelenekten kopuş bir yönü ile de yenilikçi tohumların ekildiği XVIII. yüzyıl sürecinde özellikle merkez-taşra tezgâhları arasında değişmeye başlayan bu bağımlılık ilişkisi yeniden ele alınmaya ve değerlendirilmeye çalışılmıştır. Bununla birlikte sancaklarda yeni aktörler olarak ortaya çıkan mütesellimlerin bu bağımlılık ilişkilerine nasıl dâhil edildikleri, ne gibi sorumluluklar üstlendiği, merkezin gemi yapımıyla ilgili taleplerini ne dereceye kadar yerine getirebildikleri gibi sorunlar arşiv belgelerinden hareketle aydınlatılmaya çalışılacaktır.
\end{abstract}

Anahtar sözcükler: Mütesellim, Tersane, Gemi Yapımı, Taşra

Abstract: Regarding research about the Navy department, it is necessary to explore the vein of center and country, in order to introduce the quality and the operations of this department. Especially, when we mention ship construction activity, these elements become more important. This is because, the fundamental thing to determine the quality and the operation of shipyards both in the center and the country is the dependency of each other regarding the supply of labor and materials and equipment. Inevitably, this dependency required a strict control mechanism and communication between the center and country shipyards. However, in the sanjaks, forming one of the main units of the Ottoman organized administration, structural and functional changes had occurred since the $17^{\text {th }}$ century and this situation also changed these dependency relations. In this study, the attempt is made to reconsider and evaluate this dependency relationship which began to change, especially between the central and the country arsenals, during the $18^{\text {th }}$ century, when both the seeds of the break with tradition and of innovation were planted. Mutesellims emerged as new actors in the sanjaks in this period and this paper attempts to clarify from archival documentary sources the problems, such as how the mutesellims were included within these dependency relations, what responsibilities they assumed, and how much they could fulfill the demands of the center in respect to shipbuilding requirements.

Keywords: Mutesellim, Shipyard, Shipbuilding, Rural

\footnotetext{
* Dr. Öğr. Üyesi, Akdeniz Üniversitesi, Edebiyat Fakültesi, Tarih Bölümü, Antalya. fsimsek@akdeniz.edu.tr, https://orcid.org/0000-0002-7392-826X
} 
Osmanlı İmparatorluğu genişleme siyaseti doğrultusunda topraklarına kattığı, denizci Türk beyliklerinin (Karesi, Germiyan, Menteşe, Saruhan ve Candaroğulları) mirasını sahiplenip geliştirerek karada olduğu kadar denizlerde de gücünü ortaya koymuştur. Bölgedeki Rum denizci geleneğinden de yararlanan Osmanlı İmparatorluğu; Gelibolu ve İstanbul başta olmak üzere çeşitli bölgelerde kurduğu tersanelerde inşa ettiği donanması ile Akdeniz ve Karadeniz'de güçlü rakiplerine rağmen denizlerdeki gücünü uzun süre devam ettirebilmiştir (Uzunçarş1l1 1984, 394403).

Ele alınan dönem itibariyle donanma ve gemi inşa faaliyetleri ile ilgili olarak genel manzara şu şekildeydi: İmparatorluğun İstanbul'daki ana tersanesi (Tersane-i Amire) donanmanın bel kemiği olmakla birlikte kıyı ve adalardaki tersaneler de merkezi otoritenin sıkı denetimi altında donanma ve denizcilik faaliyetlerinin yürütüldüğü önemli merkezlerdi (Özveren 2000, 21; Şimşek 2019, 202). İktisadi, sosyal ve askeri alanlarla doğrudan bağlantılı olan gemi yapımı için uzman işgücünün ve malzemenin temin edilip tersanelerde toplanması titiz ve sıkı bir planlamay1 gerektirmekteydi. İnebaht1 (1571), Girit (1655-1656) ve Çeşme (1770) deniz savaşları, donanmanın büyük oranda zarar gördüğü hatta neredeyse yok olduğu savaşlardı. Bu nedenle donanmanın neredeyse yeniden tesisi için devletin kaynakları bu yönde seferber edilerek merkez ve taşradaki diğer tersanelerde hummalı bir çalışmaya girişilirdi. Sefer zamanlarında gemi inşası çok önemli olabilmekteydi. Mesela III. Murad, İspanya Seferi öncesinde divan üyelerinden ve beylerbeylerinden masrafları kendileri tarafindan karşılanmak üzere kadırgalar inşa etmelerini istemişti. Görüldüğü üzere padişah, zaman zaman üst düzey bürokrasi mensuplarından gemi inşasıyla ilgili bir takım taleplerde bulunabilmekteydi (İnalcık, 2006, 141).

Tersane-i Amire'de yapılacak gemilerin masrafları; ilgili görevliler tarafindan tersane hazinesinden (Çeşme yenilgisinden sonra III. Selim zamanında Tersane'ye ait bir hazine kurulmuştu. Bkz. Ünal 2003, 84) veya bazı sancakların vergi kalemlerinden havale usulüyle sağlanabilmekteydi (BOA, C. BH., 8 / 374, H.1179/M.1675; BOA, İE. BH., 18 / 1601, H. 1138/M. 1726; BOA, C. BH., 84 / 4026, H.1197/1783). Ayrıca merkezde kaptanlar, reisler, kalafatçılar, kumbaracılar, marangozlar gibi zanaat kesiminden olup "Tersane Halkı" adiyla da bilinen hâlihazırda emre amade uzmanlaşmış bir işgücü vardı (Bostan 2003, 102-121; Özkaya 1994, 768). Kaldı ki Anadolu'nun bazı sancakları ocaklık olarak tersanenin bir takım malzemelerinin temini ve nakliyesinden sorumlu tutulmuşlardı (Cin 1986, 72; Göyünç 1991, 276; Kılıç 2001, 889).

$\mathrm{Bu}$ aşamada taşra tezgahlarında yapılacak gemilerin masraflarının kimler tarafından ve ne şekilde karşılandığı sorusunun yanıtlanması son derece önemlidir. Taşra tersanelerinde farklı inşa malzemelerinin ve çeşitli işkollarına mensup işçilerin organizasyonları nasıl sağlanmaktaydı? Bu malzeme ve işçi ücretlerinin finansman kaynakları neydi ve nasıl karşılanmaktaydı? Hangi görevliler bu işlere nezaret etmekteydiler? Merkez taşradaki bu görevlileri ve yapım faaliyetlerini denetlemek için nasıl bir yöntem izlemekteydi?

XVIII. yüzyı özelinde bu soruların yanıtlarını verebilmek için aslında Osmanlı taşra idari sisteminin süreç içerisinde geçirdiği değişimlerin dikkate alınması zorunludur. İdari, askeri ve mali kurumların temel birimi olan sancaklar süreç içerisinde ortaya çıkan mali, sosyal ve idari aksaklıkların ilk aşamada yansıdığı birimlerdi (Kunt 1978, 104, 1983; Kılıç 1997, 3). Bu değişimin en belirgin göstergelerinden biri sancaklarda artık klasik sancakbeyi-beylerbeyi yerine bunların vekilleri durumunda olan mütesellimlerin yaygınlık kazanmasıydı. Hatta bazı sancakların idaresi "mütesellimlikle idare olunmak" şartıyla beylere verilmekteydi ve ayanlar gibi yerel güçlerin ortaya çıkması ile mütesellimlik daha çok bu kesimlerin üslendikleri bir görev halini aldı (Şimşek 2010, 140-168). Sancaklardaki bu değişim, işlerin yürütülmesi bak1mından artık merkezin muhatap aldığ 1 kesimlerin de değişmesine yol açmıştır. Özellikle merkezi kontrolün zayıflamaya başladığı XVII. ve XVIII. yüzyıl itibariyle askeri, idari ve iktisadi 
alanda güçlenmeye başlayan ayanlar, voyvodalar (BOA, C. BH., 120 / 5814, H.1237/M.1822; Kaya, 2007; Özdemir, 2017, 140) ve mütesellimler, devletin bu konudaki ihtiyaçlarının giderilmesinde merkezden atanan görevlilere kıyasla daha etkili olmaktaydılar (Duygu 1953, 16; Özkaya 1977, 2008; Tuş 1993; Nagata 1997; Cavit 1998, 139; Özdeğer 2003; Nagata \& Emecen 2004; Canbakal 2006, 75; Yıldız 2006; Şimşek 2010). Bu bakımdan mütesellimlerin gemi inşa faaliyetlerini gerekli malzeme-işgücünün temini ve bizzat gemi yapımını üstlenmeleri şeklinde iki kategoriye ayırmak mümkündür. Ancak bu çalışmanın ana teması mütesellimlerin gemi inşa faaliyetleri olduğundan daha çok bu konu üzerinde durulacaktır.

Yerel güç odaklarından ayan ve mütesellim gibi nüfuzlu kimselerin aynı zamanda ticari işleriyle alakalı olarak birtakım gemilere tek başına veya hissedar olarak sahip oldukları görülmektedir (Çizakça 1999, 77-92; Güven 2016, 79). Örneğin XVIII. yüzyıl sonlarında Batı Karadeniz bölgesinde gemicilik faaliyetleriyle dikkati çeken Safranbolu Mütesellimi Haydutoğlu Mehmed Bey'in idamı üzerine çok sayıdaki gemisine devlet tarafından el konmuştu (Yılmaz \& Yasa 2009, 185). Yine sahip veya ortak oldukları gemiler sayesinde Caniklizadelerin Rusya ile (Bay 2007, 94-95, 393), Hazinedarzadelerin Karadeniz kıyılarında (Bay, 2007, 253-254) geliştirdikleri ticari ilişkiler buna dair örnekleri teşkil etmekteydiler. Ancak meselenin bu boyutu ayrı bir çalışma konusu olmakla birlikte temelde mütesellimlerin donanma ile ilgili sorumlukları ve inşa faaliyetleri çalışmamızın genel çerçevesi olarak belirlenmiş, kendi adlarına giriştikleri gemicilik faaliyetleri ise konumuzun dışında tutulmuştur.

Donanmaya gemi inşası için müteselimlerin görevlendirilmelerine dair dönemin belgelerine yansımış çok sayıda örnek vardır. Tersane-i Amire Emini, Sinop tersanesi'nde 2 kıta kalyon inşasına memur Kastamonu Mütesellimi El-Hacc Ali Ağa'dan gemileri Kasım'dan önce tamamlayıp İstanbul'a göndermesini istemekteydi (BOA, KK., 5768, 12/1). Menteşe Mütesellimi Ömer Ağa, 1796'da Bodrum'da bir adet 60 arşınlık kalyon inşası için görevlendirilmişti (BOA, HAT, 272 / 15926 A-B, H.1210/M.1797). Merkez, gemi inşasına ve işlerin yürütülmesine fevkalade önem vermekteydi ve başka bir görev söz konusu olduğunda öncelik inşa faaliyetlerinin yürütülmesinden yanaydı. Örneğin Anadolu Valisi maiyetine tayin edilen Menteşe Mütesellimi Ömer Ağa'nın inşasına memur olduğu kalyon işlerini aksatmaması için görev mahallinde kalarak maiyetindeki askerin kumandası için kardeşinin görevlendirilmesi istenmişti (BOA, C. DH., 48 / 2364, H.1210/M.1796). Merkezin gemi inşasına verdiği önemi ortaya koyan bir diğer önemli örnek ise Menteşe Mütesellimi Ömer'in yeni bir kalyon inşası durumunda suçunun affedileceğine dair gönderilen fermandır (BOA, C. BH:, 85 / 4060, H.1201/M.1787).

Antalya'da 35 ziralık bir kalyon inşası için Antalya eski mütesellimi Said Ağa'nın atanması örneğinde görüleceği üzere bazen eski mütesellimlerin dahi inşa için görevlendirildikleri görülür. Bu durum yukarıda değindiğimiz üzere Said Ağa'nın bölgedeki mevcut gücünden kaynaklanmaktaydı. Ağa, muhtemel ki mahalli otoritesi ve varsılllı̆̆1 ile kalyon inşaatı için gerekli organizasyonu merkezi otoritenin arzu ettiği şekilde sağlayabilirdi (BOA, KK., 5768, 12/1-2).

Adalardaki mütesellimler ise eğer adada bir tersane var ise Rodos Mütesellimi Murabitzade Hasan Kaptan'ın inşa ettirdiği firkateyn örneğinde (Gümüş 2010, 20) görüleceği üzere gemi yapımından birinci derecede sorumlu kimseler haline geliyorlardı. XVIII. yüzyılda Rodos'da büyük gemilerin inşa edildiği bir tersanenin varlığ nedeniyle genellikle buraya tersane veya donanmadan kimselerin yönetici olarak atanmasına dikkat edilmiştir (Ünen 2013, 58).

Gemi inşası, ilk aşamada finansmana, yeterli sayıda uzman işgücüne ve gerekli altyapıya bağlı olduğundan öncelikle bu sorunların çözümlenmesi gerekir. Bu sorunların çözümlenmesi aşamasında atılacak en önemli adımlardan birisi de yapımı gerçekleşecek olan gemi-gemilerin boyutlarının ne olacağının belirlenmesiydi (BOA, HAT, 272 / 15926-A-B, H. 1211/ M.1797; BOA, KK., 5768, 12/ 1 ). Tersane-i Amire, öteden beri yapılan gemilerin ne kadara mal olacağ 1 
bilgisini tecrübe yoluyla zaten edinmişti ve dolayısıyla da merkezde, yapılacak geminin ölçülerine göre masrafın ne olacağını gösteren envanter niteliğinde bazı kayıtların olduğu var sayımında bulunabiliriz. Böylelikle ne kadar işgücüne ve inşa malzemesine ihtiyaç olacağ ortaya konmakla birlikte en azından tüm bunların masraflarının kabaca belirlenmesi mümkün olabilmekteydi. Yani mütesellimler yeni bir gemi yapımına başladıklarında merkez de kendisi de geminin ortalama ne kadara mal olacağı bilgisine sahiptiler. Nitekim Antalya Mütesellimi yapacağı kalyonun “...İstanbul'a gelib 35 zira bir kıta navlon-i hümayunun masrafinı belirten defter gereğince bir yük 77.820 guruşa ...” mal olacağının farkındaydı (BOA, KK., 5768, 12/ 2).

Aslında taşradaki her tersanenin belirli bir gemi tipinde uzmanlaştığını söyleyebiliriz. Topografi, akıntılar, iklim, suların sığ olup-olmadığ 1 , başta kereste olmak üzere bölgedeki kaynak ve işgücünün niteliği hangi tipolojide bir gemi yapılacağını belirleyen etkenlerdi. Yapılan farklı gemi tipleri aynı zamanda bölgedeki deniz ticaretinin hacmini ve çeşidini yansıtmaktaydı (Delis 2012, 350-355). Bu çerçevede merkez yukarıda değinildiği üzere hangi tersanelerde ne tip gemiler yapıldığını elindeki kayıtlardan çıkarabilmekteydi. Ancak zaman zaman merkezden görevlendirilen tersane eminleri vasıtasıyla merkezin ihtiyaç duyduğu farklı tip ve boyutlarda gemiler de yapılabilmekteydi (Yiğit 2009, 124).

Bazı durumlarda işlerin aksamaması için kereste masrafları ve işçi ücretleri ilgili mütesellim tarafından karşılanır sonrasında yapılan harcamalar mütesellime geri ödenirdi (BOA, C. BH., 47/2233, H.1210/M.1796). Ancak merkezden gönderilen görevliler ve işçilerin harcırahları genellikle Hazine-i Amire (BOA, C. BH., 18 / 867, H.1210/M.1796) tarafından karşlanmakta ve yapılan ödemeler, titiz bir şekilde kayda geçirilmekteydi. Örneğin Menteşe Mütesellimi Ömer'e gönderilen bir fermanda; Hazine-i Amire defterlerine göre işçi ücretleri ve kereste gibi malzemelerin temini için kendisine 37.600 kuruşun nakit verildiği kaydedilmekteydi (Yiğit 2009, 122,124). Bazı durumlarda ise tıpkı Tersane-i Amire'de olduğu üzere bir takım vergi kalemlerinin yapılan masraflara karşılık tahsis edilmesi, finansmanın sağlanması açısından tercih edilen yöntemlerdendi. Nitekim Menteşe Mütesellimi Ömer Ağa'nın Bodrum'da yaptırdığı kalyon masrafının bir kısmın 1213 senesi cebeli bedeliyesinden sağlanması (BOA, C.BH., 66 / 3102, H.1215/M.1800), Rodos'taki yaptırılan gemiler için adanın cizye vergisi gelirlerinden veya Misır hazinesinden havale yapılması (Ünen 2013, 238), Sinop Tersanesinde yapılan kalyataların masrafının Canik sancağı sürsat bedelinden karşılanması (Bostan 2003, 18) bu uygulamaya dair örneklerdir.

Mütesellimler bizzat gemi yapımı için atandıkları gibi bazı hallerde yapılacak olan gemi masrafının karşılanması için görevlendirildikleri söz konusu olabilmekteydi. Örneğin Fırat nehri kenarında Birecik'te askeri amaçlı yapılacak gemilerin masraflarının Ayıntap mütesellimi Ahmet Ağa tarafından karşılanması istenmekteydi (Yiğit 2012, 3402). Ancak bu masrafi mütesellim kendi cebinden değil büyük olasılıkla yine bölgedeki gelir kalemlerinden karş1layacaktı.

İşçilerin tayinatlarının kimler tarafından ve ne şekilde karşılandığıyla ilgili bir belge oldukça ilginç bilgiler sunmaktadır. Buna göre Menteşe Mütesellimi Ömer Ağa, yapımı bitmek üzere olan bir kalyonun denize indirilmesi ve liman temizliği işlerini yapmak üzere merkezden bir görevli gönderilmesini talep etmekteydi. Ancak gönderilen kaptan ve maiyetindeki nefer, oymacıbaşı, dülger kalfası gibi görevlilere tayinatlarının kimler tarafından verileceği bir sorun teşkil etmekteydi. Konuyla ilgili kalemler arasındaki yazışmalardan "Taşra mahallelerde inşa olunan kalyonların tenziline memur kapudanlara yevmiye beş çift nan ve iki vukiyye köşt(?) inşaya memurlar tarafindan verilegelüb Bodrum'da inşa olunan kalyonun tenziline memur Hüseyin kapudanın ol miktar tayinat kalyon-ı mezbur inşasına memur tarafindan verilmek için tarih-i merkumda suret verildiği..." belirtilmekteydi (BOA, C. BH, 66 / 3102, H.1215/M.1800). Yine Sinop'ta yaptırılacak şehtiyede görevli Tersane-i Amire mimarı Nikola Kalfa'nın da tayinatı, şehtiye yapımı ile görevlendirilen Altıkulaç-zade Hüseyin tarafından karşılanacaktı 
(BOA, C.BH., 60 / 2841, H.1196/M.1782; Yiğit 2009, 123). Yani merkezden gelen görevlilerin tayinatları, gemiyi yapmakla yükümlü olan kişi tarafından karşılanacaktı.

Zaman zaman kalyon inşası için görevlendirilen mütesellimin ölümü veya mütesellimlik görevinden azledilmesi gibi bir takım olumsuzluklar yaşanabilmekteydi. Merkez, bu tür durumlarda yapım işlerinin aksamaması için yerine hemen bir başkasını görevlendirmekteydi. Genellikle önceki mütesellimin yerine atanan kişi halef olarak inşası süren kalyonun bitirilmesini üstlenirdi. Daha öncesinde de değinildiği üzere Menteşe Mütesellimi Ömer göreve geldiğinde kendisinden istenen hususlardan biri, önceki Mütesellim Tavaslı Ömer'in yaptırdığı kalyonu bitirmesi idi (BOA, C. BH., 857 4060, H.1201/M.1787). Yalnız yukarıda da değindiğimiz üzere kalyon inşası için görevlendirilen Antalya eski Mütesellimi Said Ağa'nın vefatı üzerine yarım kalan işlerin yürütülmesi için oğlunun atanması ilginç bir örnek arzetmektedir (BOA, KK. 5768, 12/1). Yeni atanan görevli; yapım işlerinin ne kadarının tamamlandığı, ne kadar masraf yapıldığı ve daha ne miktar paraya ihtiyaç olduğunu tespit etmek durumundaydı. Bu tespitler için izlenen prosedür, mahallinde keşif yapılması idi. Fakat bu işlerin yürütülmesinde birinci derecede sorumlu olan merkez ile ileride bir sıkıntı yaşanmaması için Tersane-i Amire'den tayin edilen bir mimar vasıtasıyla keşfin yapılması daha uygundu. Nitekim Kastamonu Mütesellimi olarak atanan Altıkulaç-zade Hüseyin Ağa, selefinin Sinop'ta inşa ettirdiği iki adet kalyonun yapımının ne aşamada olduğunu ve ne kadar para harcandığını belirleyebilmek için Tersane-i Amire'den bir mimarın görevlendirmesini talep etmekteydi (BOA, C.BH., 127 / 6157, H.1203/M.1789).

Keşif, işlerin ne kadarının tamamlandığının tespitinde önemli bir prosedürdü ancak bu yeterli değildi. Yapımı süren gemiye ne kadar masraf yapıldığ 1 ve daha ne kadar paraya ihtiyaç duyulduğunu da belirlemek gerekliydi. Bu sorun ise merkez tarafından (Tersane-i Amire Hazinesi) dikkatli bir şekilde tutulan kayıtlar esas alınarak çözümlenmekteydi. Antalya eski Mütesellimi Said Efendi'nin ölümünden sonra kalyon inşası için kendisine ödenen miktar kayıtlardan tespit edilmiş ve eğer eksik bir ödeme var ise yapımı üstlenen kişiye buna göre tersane-i amire hazinesinden ödeme yapılmıştır (BOA, KK., 5768, 12/1).

Gemi yapımı için başta kereste olmak üzere elzem malzemelerin temin edilip nakliyesi ile ilgili olarak yakın sancak mütesellimleri görevlendirilmekteydi. Gemi yapımında kullanılacak kereste özenle seçildiği gibi aynı şekilde nakliyeleri de son derece titizlik içerisinde gerçekleştirilmekteydi. Başta Tersane-i Amire olmak üzere diğer taşra tezgahları için keresteler genellikle Kocaeli, İznikmid, İznik, Karamürsel, Biga, Balıkesir, Lapseki, Edremit, Bolu, Amasra, Bartın, Sinop gibi Karadeniz ve Akdeniz'in kıyı kesimlerindeki ormanlardan temin edilmekteydi (Güler 1992, 242; Bostan 2003, 102-121). Bu nedenle sözkonusu bölgelerde görev yapan mütesellimlerden ya kereste temini ve nakliyesi ya da bu işler için bölgeye gönderilen görevlilere yardımcı olmaları istenmekteydi. Maraş Mütesellimi, Birecik’te yapılacak gemiler için kerestenin Maraş, Birecik ve Ayıntap dağlarından kesilip nakledilmesi (Yiğit 2012, 3402), Menteşe Mütesellimi ise kalyon inşası için kesilen kerestelerin nakliyesi için görevlendirilmişlerdi (BOA, C.BH., 17 / 820, H.1205/M.1791).

Kereste dışında yine yelken ve halat yapımında kullanılacak malzemelerin büyük kısmı Canik bölgesinden sağlanmaktaydı ve Canik bu önemini XIX. yüzyıl boyunca da korumuştu (Bostan 2003, 140-143; Bay 2007, 229). Bu nedenle Canik mütesellim-muhassıl ve ayanlar1 sıklıkla söz konusu ihtiyaçların giderilmesi için görevlendirilmişlerdi (BOA, C. BH., 246 /11382, H.1201/M.1787; BOA, C. BH., 15 / 708, H.1184/M.1770; BOA, A.E., SMST.II., 71636, H. 1122/M.1710).

Merkez yalnızca mali açıdan değil zaman zaman gemi yapımı için gerekli "ahen-i ham" denen ham demir (BOA, C. BH., 47 / 2233, H.1210/M.1796; BOA, C. BH., 63 / 2977, H.1200/M.1786; BOA, C. BH., 127 / 6157, H.1203/M.1789), bakır "nühas" (BOA, C. BH., 176 
/ 8286, H.1206/M.1792) gibi malzemeleri de Cebehane-i Amire'den temin edip göndermekle mükellefti. Diğer taraftan donanmayla ilgili görevler yalnızca gemi inşasından ibaret değildi. Gemilerin silah ve teçhizatlarının temini ve imalatı da en az gemi inşası kadar önemli hususlardı. Dolayısıyla gemide kullanılacak topların ve diğer bazı aksam için gerekli malzemelerin temini konusunda ilgili sorumlularla birlikte mütesellimler görevlendirilmekteydi. Örneğin Trabzon kadısı ve müteselliminden kalyon toplarının dökülmesi için 11.212 vukiyye nühasın gönderilmesi istenmekteydi (BOA, MAD, 2973, 25/1, H. 1123/M.1711).

Bununla birlikte taşradaki tezgahlarda yapılacak donanma gemileri için inşa işlerine nezaret etmek üzere genellikle merkezden tersane eminleri veya bir takım özel görevliler gönderilmekteydi (Ünal 2008, 359; Gümüş 2010, 21). Bu Tersane eminleri veya görevliler; hem gemi inşasına nezaret etmekte hem de gemi yapımı esnasında İstanbul veya diğer merkezlerden gelecek malzeme ve giderler hakkında merkezi bilgilendirmekteydiler. Örneğin Sinop'ta 2 adet kalyonun yapımını üstlenmiş olan Kastamonu Mütesellimi'nin bir kalyonun inşasını bitirdiği ancak diğer kalyonun inşası için gerekli til ve sütun masrafları ile demir bahasının karşılanması gerektiğine dair merkezden görevlendirilen eminin gönderdiği yazı (BOA, C. AS. 862 / 33906) buna örnek verilebilir. Diğer taraftan müteselimlere merkezden gelen emirlerde; yaptırdıkları kalyonların hangi aşamada oldukları sık sık sorulmakla birlikte donanma gemi sayısının artması için işlerin sıkı tutulması tembih edilmekteydi (BOA, C. BH., 39 / 1855, H.1206/M.1792). Devlet, bu şekilde hem taşrada yaptırdığı gemilerin yapım aşamaları hakkında bilgi almakta hem de işlerin titizlikle yürütülmesi ve bitirilmesi bakımından denetim gücünü kullanabilmekteydi. Ayrıca mütesellimlerin gemi yapım aşamasında ihtiyaç duyduğu malzeme, işgücü ve masrafların temini gibi hususlar merkez ile iletişimi zorunlu kılmaktaydı (BOA, C. BH., 176 / 8286, H.1206/M.1792; BOA, C. BH., 68 / 3237, H.1197/M.1783; BOA, C. BH., 47 / 2733, H.1210/M.1796; BOA, C. BH., 63 / 2977, H.1200/H.-1786).

Taşra tezgahlarında yapılan gemilere nezaret etmek üzere merkezden bir görevlinin atanması dışında bazı yerel görevlilerin de bu amaçla görevlendirildikleri görülür. Örneğin İnegöl Ayanı Derviş Paşazade Numan Bey, III. Selim Dönemi donanma reformları esnasında Gemlik Tersanesi'ne emin olarak atanmıştı. Bu atamada gemi direklerinde ve küreklerde kullanılan gürgen ağaçlarının İnegöl ve Domaniç’ten temin edilmesi önemli bir etkendi (Güven 2016, 78-79).

Özellikle belirli merkezlerde zaman zaman gemi inşa faaliyetlerini sekteye uğratacak olumsuzluklar gözden kaçmıyor değildi. 1774 Küçük Kaynarca Antlaşması ile Ortodoks hamiliğine soyunan Rusya, gemi inşası için gerekli işgücünün sağlandığı başlıca merkezlerden olan Ege ve Akdeniz adalarından çok sayıdaki Rum'u kendi donanmasında istihdam etmeye başlamıştı (Roucek 1953, 83; Ünen 2013, 243). Rum metropolidi ve ada Kocabaşılarına gönderilen Rumca nasihatnamelerde; düşman gemilerine adam vermemelerine dair ihtarlarda bulunulmaktaydı (BOA, HAT, 267 /15525, H.1204/M.1790; Şimşek, 2019, 203). Antalya Naibi'nin ilamından sadece Rumların değil, Ermeni ve Yahudilerin de Osmanlı limanlarına uğrayan gemilere tayfa olarak yazıldıkları anlaşılmaktadır (BOA, A.E., SABH.I, 70/4863, H.1209/ M.1794). Bu durum hiç şüphesiz hem kalifiye işgücünün kaybı hem de adalardaki sosyaliktisadi yapının çözülmesi anlamına gelmekteydi. Nitekim belgede de "güvenlik" ve "mülk" bakımından olumsuz görülen bu uygunsuzlukların önlenmesi için yabancı gemilere yazılanların emlak-eşyasının zaptolunub akrabalarının haklarından gelinmek üzere isimlerinin İstanbul'a bildirilmesi istenmekteydi (BOA, A.E., SABH.I, 70/4863, H.1209/M.1794).

Mütesellimlerin inşa görevleri yanında gemi yapım malzemelerini ve gerekli işgücünü sağlaması gibi bu tarz görevleri merkez için son derece önemliydi. Özellikle seferlerden hemen önce veya sonrasında bu alanlarda yaşanacak herhangi bir yetersizlik veya olumsuzluk donanma işlerinin aksamasına yol açabilirdi. Bunun için donanmanın ana malzemelerinin ve işgücünün sağlandığı bu rezervlerin korunmaları ve iyi idare edilmeleri gerekliydi. Nitekim tersanenin 
kereste ihtiyacının büyük kısmını karşılayan ve mütesellimler tarafından idare edilen Kocaeli sancağının iyi idare edilmemesi gerekçe gösterilerek nizamın sağlanması için sancak, Mir-i Miran Mustafa Paşa'ya tevcih edilmişti (BOA, HAT, 198 / 10014, H.1206/M.1792). Mütesellimlerin kalabalık maiyetleri ile gelir tahsil etmek üzere sancak ve kazalara gelmeleri, gemi inşasında çalışan ameleyi tedirgin etmekteydi. Özellikle XVIII. yüzyılda adeta kronik bir sorun halini alan yöneticilerin kalabalık maiyetlerinin haksız talepleri halkı sıkıntıya sokmaktaydı. Bu tarz sorunların yaşanmaması, kalyon işçilerinin tedirgin edilmemesi için kalyon bitimine kadar tahsilat için az sayıda kişilerin görevlendirilmesi talep edilmekteydi (BOA, C. BH., 18 / 841, H.1206/M.1792 ).

Görüldüğü üzere XVII. yüzyıldan itibaren gücünü giderek artıran yerel unsurlardan (ayaneşraf-voyvoda-mütesellim) "yararlanabilmek" ya da "baş edebilmek" adına devletin bir takım çözüm mekanizmaları geliştirdiği dikkat çekmektedir. Taşradaki yerel güçlerin bir "müttefik" mi, yoksa ezeli bir "asi" mi olduğunu belirleyen yegâne ölçüt; devletin "de facto" olarak bu unsurlarla yaptığ 1 işbirliğiydi. Merkezin bu kesimler karşısında kendini konumlandırdığ 1 yerden bakacak olursak; kendi politikalarını yerel güçler vasıtasıyla taşrada bir ölçüde uygulayabilmesi başarı addedilebilir. Özellikle iltizam sistemi nedeniyle toprak ve sermaye üzerinde denetimi zayıflayan merkez için bu pek azımsanacak bir başarı değildi.

Nitekim herhangi bir tehdit sözkonusu olduğunda merkez Tersane-i Amire dışında taşra tezgâhları da donanma için hummalı bir şekilde yapım faaliyetlerini artırmaktaydı. Bu çerçevede devlet; denizcilik politikaları bakımından donanmasını kuvvetlendirmek maksadıyla taşradaki mütesellim, ayan ve voyvodaları bu amaçla görevlendirmiş ve kaynaklar ihtiyaç duyulan sahalara yönlendirilmeye çalışılmıştır. Malzeme ve işgücü temini hususunda hem merkez hem de diğer mahallerle sürekli irtibat halinde olunması ile taşradan merkeze, merkezden taşraya dolaylı da olsa en azından çift yönlü bir denetimi mümkün kılmıştır. Konuya ilişkin emirlerin elverişli kaynaklara, tecrübeye ve işgücüne sahip olan sancakların mütesellimlerine gönderilmesi; bu yapım faaliyetlerini daha da somut hale getirmektedir.

Özellikle yeni keşfedilen bakir kıtaların ve diğer sömürgelerin sağladığı ucuz malzeme ve işgücü sayesinde Avrupa, artık daha farklı denizlere yelken açmıştı (Özveren 2000, 21). Denizaşırı bu yerler, Avrupa için iktisadi açıdan son derece önemli olduğundan önceki dönemlere kıyasla bu yerlerde kontrolü sürdürmek adına donanmalar önem kazanmaya başladı (Neilberg 2011, 59; Parker 2014, 132-135). Yani bir anlamda denizlerin hakimiyeti demek zenginlik demekti. Nitekim bu durum, Avrupa'nın askeri ve ekonomik bir güç olarak denizciliğinin gelişiminde en önemli güdüydü. $\mathrm{Bu}$ süreçte gelişmeye başlayan yeni yöntemler, özellikle sanayi devrimi ile önemli ilerlemelerin kaydedilmesi artık geleneksel gemicilik yöntemlerini geçersiz kıldı.

Osmanlı dünyası aslında bu gelişmelerden tümüyle kopuk değildi. En azından İnebahtı Savaş1 (1571) gibi oldukça erken sayılabilecek bir dönemde bu gelişmeleri kötü bir yenilgi ile tecrübe etmişti. Ancak girişilen reform hareketlerine rağmen Osmanlı'nın geleneksel dünyasında bu konuda çok fazla bir gelişme kaydedilemedi (Gencer 2001, 59). Reformlar için her ne kadar dışarıdan uzman kişiler getirilmiş ve bir takım düzenlemelere gidilmiş ise de bunların benimsenmesi ve devam ettirilmesi için farklı bir zihniyet dünyası da yaratmak gerekliydi. Kaldı ki yenilik konusunda istekli ve gayretli bir zihinsel dünyanın yaratıldığı farz edilse bile devletin gerekli bilgi, tecrübe ve alt yapıya sahip olmaması (Berktay \& Tosun 2007, 105-106) bu konudaki gayretleri boşa çıkarmıştır. Ağır kayıplarla sonuçlanan kara ve deniz savaşları, ülke genelinde görülen çöküş emareleri devletin içte dışta yaşadığı ciddi problemler bu yöndeki çabaları etkisiz kılmış ve Osmanlı donanması eski haşmetli gücünden giderek uzaklaşmıştır.

\section{Yazar Notu:}

Bu makale "Anadolu Sancaklarında Mütesellimlik Kurumu (XVIII. Yüzyıl)” başlıklı doktora tez çalışmamızın bir bölümünün gözden geçirilerek genişletilmiş halidir. 


\section{KAYNAKÇA}

\section{Arşiv Vesikaları}

BOA, Ali Emiri, Sultan Mustafa II Evrakı (A.E.SMST.II); 71636, 22 Ş 1122 (16 Ekim 1710).

BOA., Ali Emiri, Sultan Abdülhamit I Evrakı (A.E.SABH.I); 70-4863, 15 Ca 1209 (8 Aralık 1794).

BOA, Cevdet Askeriye Evrakı (C. AS.): 862 / 33906, 11 M 1202 (23 Ekim 1787).

BOA., Cevdet Bahriye Evrakı (C. BH.): 8-374, 13 Ra 1179 (30 Ağustos 1765); 84-4026, 11 Ş 1197 (12 Temmuz 1783); 120-5814, 9 Ca 1237 (22 Şubat 1822), 47-2233, 23 Z 1210, (29 Haziran 1796); 18867, 27 L 1210, (5 Nisan 1796); 66-3102, 28 S 1215 (21 Temmuz 1800); 60-2841, 16 Ca 1196, (29 Nisan 1782); 85-4060, 29 R 1201 (18 Şubat 1787); 127-6157, 12 Ca 1203, (8 Şubat 1789); 17-820, 28 B 1205 (2 Nisan 1791); 246-11382, 16 L 1201 (1 Ağustos 1787); 15-708, 7 Ş 1184 (26 Kasım 1770); 63-2977, 19 L 1200 (15 Ağustos 1786); 176-8286, 14 Za 1206 (4 Temmuz 1792); 39-1855, 6 L 1206, (28 Mayıs 1792); 68-3237, 8 B 1197 (9 Haziran 1783); 18-841, 5 N 1206 (27 Nisan 1792).

BOA., Cevdet Dahiliye Evrakı (C. DH.): 48-2364, 29 Ca 1210, (10 Ocak 1796).

BOA., Hatt-ı Hümayun Evrakı (HAT): 272-15926-A, B, 29 Z 1211 (13 Şubat 1797); 198-10014, 29 Z 1206 (16 Ağustos 1792); 267-15525, 29 Z 1204 (9 Eylül 1790).

BOA, İbnü'l Emin Bahriye Evrakı (İE.BH.) 18-1601, 18 Za 1138 (18 Temmuz 1726)

BOA., Kamil Kepeci Defter Tasnifi (K.K.d.): 5768.

BOA., Maliyeden Müdevver Defter Tasnifi (MAD): 2973.

\section{İkincil Kaynaklar}

Bay A. (2007). Trabzon Eyaletinde Mütegallibe Hareketleri ve Ayanlık (1750-1850). Yayımlanmamış Doktora Tezi, Atatürk Üniversitesi, Erzurum.

Berktay H. \& Terzioğlu T. (2007). “Osmanlı Denizlik Tarihinin Evrensel, Karşılaştırmalı ve Teorik Çerçeveleri”. Ed. Özlem Kumrular. Türkler ve Deniz, 93-145. İstanbul

Bostan İ. (2003). Osmanlı Bahriye Teşkilatı: XVIII. Yüzyılda Tersane-i Amire. Ankara 2003.

Canbakal H. (1999). Ayntab at the End of the Seventeenth Century: A Study of Notables and Urban Politics. Yayımlanmamış Doktora Tezi, Harvard University, Boston. 1999.

Cavit A. (1998). Hadika-i Vekayi. Haz. Adanan Baycar, Ankara 1998.

Cin H. (1986). Miri Arazi ve Bu Arazinin Özel Mülkiyete Dönüşümü. Konya 1986.

Çizakça M. (1999). Íslam Dünyasında ve Batı'da İş Ortaklıkları Tarihi. Çev. Leyla Layıkel, İstanbul 1999.

Delis A. (2012). "Mediterrenean Wooden Shipbuilding in the Nineteenth Century: Production, Productivity and Ship Types in Comparative Perspective". Cahiers de la Mediterranee 84 (2012) 349-366.

Duygu S. (1953). Yozgat Tarihi ve Çapanoğulları. İstanbul 1953.

Gencer A. İ. (2001). Bahriye'de Yapılan Islahat Hareketleri ve Bahriye Nezareti'nin Kuruluşu (17891867). Ankara 2001.

Göyünç N. (1991). "Yurtluk-Ocaklık Deyimleri Hakkında". Tarih Araştırmaları Merkezi (Bekir Kütükoğlu’na Armă̆an). İstanbul (1991) 267-277.

Güler İ. (1992). XVIII. Yüzyılın İlk Yarsında Sinop (İdari Taksimat ve Ekonomik Tarihi). Yayımlanmamış Doktora Tezi, Marmara Üniversitesi, İstanbul.

Gümüş Ş. Ö. (2010). “Osmanlı’da Gemilerin Denize İndirilmesi”. Celal Bayar Üniversitesi Sosyal Bilimler Dergisi 8/1 (2010) 15-36.

Güven T. (2016). “Osmanlı İmparatorluğu'nda Ayanlar, Sermaye Birikimi ve Girişimcilik”. Türkiye Íslam İktisadı Dergisi III/I (2016) 63-88.

İnalcık H. (2006). Osmanlı İmparatorluğu'nun Ekonomik ve Sosyal Tarihi. C. I. İstanbul: Eren Yayınları.

Kaya K. (2007). Osmanlı Imparatorluğu’nda Voyvodalık. Yayımlanmamış Doktora Tezi, Ankara Üniversitesi, Ankara.

Kılıç O. (2001). "Beylerbeyilikler/ Eyaletlere, Kaptanlıklar, Voyvodalıklar, Melikler (1362-1799)". 
Türkler IX (2001) 897-8.

Kılıç O. (1997). 18. Yüzyllın İlk Yarısında Osmanlı Devleti'nin İdari Taksimatı-Eyalet ve Sancak Tevcihatı. Elazığ 1997.

Kunt İ. M. (1978). Sancaktan Eyalete (1550-1650 Arasında Osmanlı Ümerası ve İl İdaresi). İstanbul 1978.

Kunt İ. M. (1983). The Sultan's Servants the Transformation of Ottoman Provincial Government (15501650). New York 1983.

Özkaya Y. (1994). "XIX. Yüzyılda Mudurnu'nun Sosyal ve İktisadi Durumu”. XII. Türk Tarih Kongresi'ne Sunulan Bildiler (12-16 Eylül 4-8 Ekim 1994), C. III. Ankara (1994) 763-772.

Özkaya Y. (1977). Osmanlı Imparatorluğu'nda Ayanlık. Ankara 1977.

Özkaya Y. (2008). 18. Yüzyılda Osmanlı Toplumu. İstanbul 2008.

Özdemir Y. (2017). "Bir Voyvodanın Ölümü: Katipzade Hacı Mehmet Efendi'nin İdamı”. İzmir Araştırmaları Dergisi 6 (2017) 137-152.

Özveren Y. E. (2000). "Shipbuilding 1590-1790”. Ed. I. Wallerstein, Review 23/1(2000) 15-86. Newyork, Research Foundation of State University of New York \& Fernand Braudel Center.

Nagata Y. (1997). Tarihte Ayanlar Karaosmanoğulları Üzerinde Bir Deneme. Ankara 1997.

Nagata Y. \& Emecen F. (2004). "Bir Ayanın Doğuşu: Karaosmanoğlu Hacı Mustafa Ağa'ya Ait Belgeler”. Belgeler XXV/29 (2004) 1-67.

Neilberg M.S. (2011). Dünya Tarihinde Savaş. Çev. M. T. Akad, İstanbul 2011.

Özdeğer M. (2003). "Ayan Era in the Ottoman Government”. Kirgızistan-Türkiye Manas Üniversitesi Sosyal Bilimler Dergisi 6 (2003) 29-42.

Parker G. (2014). Cambridge Savaş Tarihi. Çev. F. Tayanç-T. Tayanç, İstanbul 2014.

Roucek J.S. (1953). "The Geopolitics of the Mediterranean II". American Journal of Economics and Socilogy 13/1 (1953) 71-86.

Şimşek F. (2010). Anadolu Sancaklarında Mütesellimlik Kurumu (XVIII. Yüzyll). Yayımlanmamış Doktora Tezi, Akdeniz Üniversitesi, Antalya.

Şimşek F. (2019). "19. Yüzyılın İkinci Yarısında Cezayir-i Bahr-i Sefid Vilayetinde Kaçak Gemi Yapımı". Belleten LXXXIII/296 (2019) 201-227.

Tuş M. (1993). Sosyal ve Ekonomik Açıdan Konya (1756-1856). Yayımlanmamış Doktora Tezi, Ankara Üniversitesi, Ankara.

Uzunçarşılı İ. H. (1984). Osmanlı Devleti'nin Merkez ve Bahriye Teşkilatı. Ankara 1984.

Ünal U. (2003). "III. Selim Döneminde Osmanlı Bahriyesi”. Askeri Tarih Araştırmaları Dergisi I/1 (2003) 81-93.

Ünal M. A. (2008). Osmanlı Devrinde Sinop. Isparta, Fakülte Kitapevi.

Ünen U. (2013). XVIII. Yüzyllda Osmanlı İdaresinde Rodos Adası. Yayımlanmamış Yüksek Lisans Tezi, Adnan Menderes Üniversitesi, Aydın.

Yıldız S. (2006). XVIII. Yüzyılda Manisa'da Gündelik Hayata İlişkin Bir Değerlendirme. Yayımlanmamış Yüksek Lisans Tezi, Ankara Üniversitesi, Ankara.

Yılmaz S.\& Yasa N. (2009). "Viranşehir (Safranbolu) Mütesellimi Haydutoğlu Mhmet Bey". Türk Dünyası Araştırmaları Dergisi 178 (2009) 177-188.

Yiğit A. (2009). "165 Nolu Bodrum Şeriyye Sicilinde Bulunan Denizciliğe Dair Kayıtlar". Muğla Üniversitesi Sosyal Bilimler Enstitüsü Dergisi 22 (2009) 117-138.

Yiğit A. (2012). "Osmanlı Devleti’nin Payas ve Birecik Limanları Üzerinden Bağdat'a Askeri Malzeme Nakline Dair Ayıntab Şer'iyye Sicillerinden Bazı Belgeler". 38. ICANAS Uluslararası Asya ve Kuzey Afrika Çalışmaları Kongresi (Ankara 10-15 Eylül 2007). Ankara (2012) 3397-3418. 
